\title{
JUDICIABILIDADE DOS ATOS POLÍTICOS OU DE GOVERNO NO BRASIL NO CONTEXTO DOS DIREITOS E GARANTIAS FUNDAMENTAIS DO CIDADÃO (EM HOMENAGEM AOS VINTE ANOS DA CONSTITUIÇÃO CIDADÃ)
}

William Couto Gonçalves*

\section{RESUMO}

Busca o presente trabalho sobre Ato Politico ou de Governo e sua Judiciabilidade, a partir de uma contextualização histórica, com ênfase para os seus precedentes de origem jurisprudencial, legislativa e doutrinal, identificá-lo no curso do pulsar histórico da ordem jurídicoconstitucional brasileira, com os adereços da melhor doutrina pátria atual, para se concluir pela sua judicialização quando praticado além dos limites que lhe são impostos pela Constituição.

Palavras-chave: Ato Político. Ato de governo. Judiciabilidade.

\begin{abstract}
The current assignment on Political or Governmental act and its legality, from a historical context, highlighting its precedents with jurisprudential, Legislative and doctrinal origins, with the aim of recognizing that throughout the course of the historical continuity of the Brazilian Legal-Constitutional order, alongside with the features
\end{abstract}

* $\quad$ Doutor em Direito (UGF-RJ); mestre em Ciências Jurídicas (UL-PT); pós-doutor em Filosofia do Direito (ABF-RJ); especialista em Direito do Estado (UGF-RJ); especialista em Direito Civil e Direito Processual Civil (UGF-RJ); especialista em Direito Penal e Processual Penal (UGF-RJ); professor de Ontologia das Garantias Constitucionais do Processo no Programa de Mestrado em Direito das Faculdades Integradas de Vitória (FDV), Estado do Espírito Santo; Juiz de Direito de Entrância Especial-ES. 
of the best current National Doctrine, to conclude its judiciousness when it's used beyond the limits imposed by our Constitution.

Keywords: Political act. Government act. Judiciary.

\section{INTRODUÇÃO}

No ano em que se comemora o vigésimo aniversário da atual Constituição da República, convém haja reflexões sobre temas que digam respeito à História do Direito Constitucional pátrio.

É uma modesta maneira, posto que científica, de se prestar homenagem àquela que já deixou todas as infâncias, a adolescência, a juventude e alcançou a idade adulta: vinte anos!

Há aqui um questionamento: Se o Ato Político ou de Governo é ou não passível de Judiciabilidade no contexto dos Direitos e Garantias Fundamentais do Cidadão.

Este Feliz Aniversário, tem como objetivo demonstrar que só é possível identificar o Ato Político ou de Governo e sua Judiciabilidade no Brasil a partir da Primeira República, ou seja, a partir da Constituição Republicana de 1889, não obstante encontrarem-se exemplares de Atos Políticos ou de Governo na Constituição Imperial de 1824, mais precisamente nas atribuições do Chefe do Poder Executivo e do Poder Moderador.

Ver-se-á que, com a assimilação da forma Republicana de Governo e a elaboração de uma Constituição que se fez conforme o modelo Americano do Norte e, sobretudo, somente após a verificação fática de Atos que, pela sua natureza, mostraram-se similares aos Atos Políticos ou de Governo da jurisprudência francesa, e mais ainda a partir do engenho intelectual de Rui Barbosa, é que, no Brasil, deu-se a ocorrência concreta e o enfrentamento do tema pertinente aos Atos Politicos ou de Governo e sua Judiciabilidade.

Para o desenvolvimento racional dos presentes estudos buscouse da vertente historicista um enfoque generalizado dando-se ênfase à gênese dos Atos Políticos ou de Governo a partir dos seus precedentes determinantes de origem jurisprudencial francesa, sem se olvidar de sua origem legislativa para se concluir, ao fim, que a assimilação da 
Teoria do Ato Político ou de Governo se deu em vários países, inclusive no Brasil. Fez-se, por conseguinte, uma estudo de História do Direito.

Após essa contextualização histórica do tema cuidou-se de demonstrar que, no Brasil, a História do Direito, se deu por um processo de transformações culturais, que culminou com a adoção do Regime Republicano Federativo organizado nos termos de uma Constituição Republicana.

Para se chegar a esse estágio perpassou-se, mesmo que em sinopse, pelos sub-períodos do Período Colonial, bem como pelos subperíodos do Período Imperial, até que se chegasse ao terceiro e último Período, o Republicano.

Buscou-se identificar a primeira vez em que se questionou no Brasil a Judiciabilidade dos Atos Políticos ou de Governo, o que se deu no alvorecer da Primeira República, quando da declaração do estado de sítio, atos praticados pelo Poder Executivo no seu antes e no seu pós, extrapolando os limites traçados pelo Texto Constitucional, afetaram direitos e garantias individuais que, por direito e justiça, não poderiam ser afetados.

Mostrou-se que, quando Rui Barbosa formulou seu questionamento perante a Justiça Federal sobrea inconstitucionalidade dos atos praticados pelo Chefe do Poder e pretendeu que os seus defendidos fossem reparados civilmente pelos danos sofridos, dele próprio colheu-se a asserção: “É a primeira vez que, neste paiz, se intenta uma acção desta natureza". ${ }^{1}$ (In verbis).

A partir da Constituição de 1891, demonstrou-se o quanto foram influenciadas as demais Constituições brasileiras quando da regulação dos Atos Políticos ou de Governo e sua Judiciabilidade, a ponto de ter-se constatado, na imediata Constituição de 16 de julho de 1934, que, no seu artigo 68, cuidou de vedar expressamente ao Poder Judiciário o conhecimento de questões tidas como de natureza exclusivamente políticas.

As demais Constituições, de 1937, 1946, 1967 e 1988, mantiveramse silentes quanto a judiciabilidade ou não dos Atos Políticos ou de Governo, mas demonstrou-se no fim, que não obstante o silêncio do constituinte, a judiciabilidade dos Atos Políticos ou de Governo é inerente de um regime jurídico-constitucional-democrático, por isso não 
é possível mesmo ignorá-la quando se dá a afetação de direitos e garantias do cidadão além do que expressamente se permite pela Carta Maior.

Por derradeiro, mostrou-se o quanto a doutrina brasileira pelas vertentes de Celso Antônio Bandeira de Mello, Maria Sylvia Zanella Di Pietro e Hely Lopes Meirelles, é unívoca em admitir a judiciabilidade dos Atos Políticos ou de Governo quando assentes no arbítrio.

\section{DO FUNDAMENTO HISTÓRICO DOS ATOS POLÍTICOS OU DE GOVERNO E SUA JUDICIABILIDADE}

\subsection{PRECEDENTES DETERMINANTES DE ORIGEM JURISPRUDENCIAL}

Da vertente historicista pode-se extratar duas fontes e dois momentos históricos dos Atos Políticos ou Atos de Governo. O primeiro deles está na jurisprudência do Conselho de Estado francês ao tempo da Restauração borbônica quando se deram as negativas, pelo mesmo Conselho, aos reclames que tinham como suporte fático a queda e a extinção do regime napoleônico e as substituições políticas que dele decorreram. Convém registrar que não há unanimidade no apontamento desta base histórica, mas, força é convir, que sua inserção na corrente majoritária liderada por Duez ${ }^{2}$ na sua obra "Les actes de gouvernement", de 1935, é inquestionável. Para Duez o Ato Político ou de Governo tem sempre uma fundamentação política e na sua essência está uma exigência maior do Estado. Por isso os Tribunais, na maior das vezes, não estão aptos a exercerem o seu controle. Acrescenta, ainda, que "em França, a matéria dos atos de Governo é o fruto de uma política jurisprudencial do Conselho de Estado."

Não obstante, afirmar que uma das origens está na jurisprudência do Conselho de Estado francês não satisfaz, impõe-se aclarar quais as circunstâncias fáticas e históricas que determinaram a conduta do aludido Conselho.

Buscava-se, originariamente, vitalizar a moral administrativa francesa que se via, por força do Antigo Regime, apoucada ante a ingerência plena e direta dos juízes nos projetos traçados pela Pública Administração. A inquietude que permeava a relação entre os limites 
de atuação dos juízes e a administração estatal está límpida no texto do Deputado Thouret, na seção de 24 de março de 1790, quando fez registrar que "autorizado a revisar e rebater as ordenanças e editos reais ... o juiz se converteu no rival do poder administrativo, perturbando suas operações, paralisando seus movimentos e inquietando seus agentes." 3

De igual modo, faz alusão a essa desconfortante relação no plano endógeno de segmentos do Estado, Sanchez Moron", afirmando que, nos últimos anos do Acien Regime, os "parlamentos", que equivalem aos órgãos judiciais, reduto da aristocracia..., revigoraram seus antigos poderes, sobretudo os que lhes reservavam a faculdade de revisar e vetar os programas reais, como requisito imprescindível para que os tais programas fossem colocados em prática. Desse modo, se opuseram com eficácia às reformas econômicas e sociais que os Ministros da Monarquia Absoluta quiseram introduzir no fim do século XVIII, precipitando assim a Revolução. Por isso, o Código Penal revolucionário de 1791 tipificou como delito toda ingerência dos juízes nas tarefas da Administração, de maneira que a divisão de poderes, no que se refere às relações entre o Executivo e os tribunais, foi interpretada como estrita separação de poderes e funções. As decisões do Governo e dos seus agentes administrativos seriam executadas por si mesmas, gerando diretamente a obrigação de cumpri-las, sem que nenhum poder constituído pudesse opor-se a elas. Havia, como se vê, um desafio dos tribunais à autoridade do próprio Estado.

Foi, precisamente, esse estado de coisas que determinou, ao tempo da Restauração (1815-1830), que a jurisprudência do Conselho de Estado, este criado por força do artigo 52 da Constituição de 1799, traçasse, de forma mais bem delineada, os contornos do Ato Politico ou Ato de Governo. Antes, contudo, de que tais contornos fossem traçados, situações pontuais determinaram o surgimento da noção de Ato Politico ou de Governo.

Tal noção surgiu na medida em que os liberais e os monárquicos expunham acirradas críticas à criação do aludido Conselho. Os primeiros, os liberais, reprovavam sua origem autoritária como juiz administrativo. Isso porque o dispositivo constitucional que deu origem ao Conselho diz que "sob a direção dos Cônsules um Conselho 
de Estado se encarregará de redigir os projetos de lei e os regulamentos da Administração, e de resolver as matérias que sejam de natureza administrativa." ${ }^{5}$ Os segundos, os monárquicos, se opunham ao Conselho porque consolidou a situação dos adquirentes de bens nacionais, aplicando a lei de confisco dos bens dos desterrados.

Nesse contexto de críticas e oposições, o Conselho de Estado apouca, espontaneamente, os limites das suas próprias atribuições em dois campos distintos. No primeiro, diminui o alcance do princípio da divisão de poderes, em benefício dos tribunais ordinários. No segundo, confere aos órgãos da Administração ativa a solução das matérias de grande relevo político. Aqui, precisamente, e nestas circunstâncias, o Conselho de Estado que buscou mostrar-se modestamente para se manter como tal, formula a noção de Ato Político que a jurisprudência consolidou. Assim, tem-se que, o Conselho de Estado optou por limitar a sua própria jurisdição em favor dos tribunais e do poder político, a ser eliminado pelo Novo Regime.

\subsection{DA GÊNESE JURISPRUDENCIAL}

Deu-se, a partir desse momento, por um período que compreendeu os anos de 1822-1875, o surgimento da Teoria do Móvel Político, do também denominado Ato de Governo. O arresto Lafitte, de 01 de maio de 1822, inaugurou esse período. $\mathrm{O}$ caso teve como suporte fático a renda outorgada por Napoleão à princesa Borghese que, por sua vez, repassou-a ao banqueiro Lafitte. Não pagas as rendas, e vencido Napoleão em Waterloo, uma lei de 12 de janeiro de 1816 privou os membros da família Bonaparte de todos os bens adquiridos a título gratuito e, entre tais bens, a renda da princesa. Lafitte, que havia recebido o crédito, após várias reclamações ao Estado, interpôs ao Conselho de Estado uma medida contenciosa pleiteando o recebimento da renda. O Conselho de Estado declarou-se incompetente para apreciação do pleito porque "... la réclamation tient à una question politique dont la décision appartient exclusivement au Gouvernement". ${ }^{6}$

Outros conflitos relativos à reclamação de patrimônio devido a membros das famílias reinantes se sucederam, como dão conta os arrestos "Famille Napoleon" e "Héritiers de Napoleon", cujos reclames exigiam, por parte do Conselho de Estado, a interpretação de vários convênios internacionais - em especial o Tratado de Fointeneblau 
- e uma boa soma de decretos governamentais, os quais receberam idênticas respostas judiciais de incompetência, por tratarem-se de “... actes de gouvernement ayant un caractère essentiellement politique... dont l'interpretation et l'exécution ne peuvent nous être déférées par la voie contentieuse". A par desses casos, tem-se o da viúva de Murat, considerado pelo Conselho de Estado não como Ato de Governo ou Ato Político, sim Ato Diplomático.

Nos três casos, o Conselho de Estado rejeitou as pretensões deduzidas, sendo que os dois primeiros foram considerados Atos de Governo de considerável conteúdo Político, e o terceiro, Ato Diplomático. Denominações distintas devidas à qualidade dos pleiteantes, os dois primeiros, da família imperial, o terceiro não da família imperial. Essa distinção entre Atos Políticos ou de Governo e Ato Diplomático esteve evidente, outrossim, no caso do príncipe Louis Napoleon, no arresto de 22 de agosto de 1844 .

Contudo, certo é que a Teoria do Ato Político ou de Governo excede os limites subjetivos de membros da realeza para fazer-se presente nas questões de outros cidadãos comuns que se viram prejudicados com atos praticados pelo Poder Público sob inspiração política. Um dos casos está no arresto Duc d'Aumale, de 09 de maio de 1867, quando o Conselho de Estado se declarou incompetente para conhecer o recurso interposto por excesso de poder que o Duque d'Aumale e o editor Michel Lévy interpuseram contra a resolução do Prefeito de Polícia e da decisão do Ministro do Interior que ordenou o seqüestro do livro "L'Histoire des Princes de Condé", sob o argumento de que "... ces mesures sont des actes politiques qui ne sont pas de nature à nous être déférées pour excés de pouvoir en notre Conseil d'Etat au contentieux."7

Outro dos casos diz respeito ao Monsieur Lucas, de 01 de fevereiro de 1851, que decidiu sobre a indenização pelos prejuízos possíveis de produzir ao demandante a liberdade de um preso, ordenada pela autoridade local em Tahiti. O Ministro da Marinha, assim se expressou: “Entre os condenados estão jovens pertencentes às primeiras famílias do país, e nestas circunstâncias sua prisão produzirá perniciosos efeitos, por isso o Governo ordenou sua liberdade." Esta medida "purament politique n'était pas de nature à conferer au sieur Lucas un droit pécuniaire contre l'Etat."

O Conselho de Estado manteve a decisão ministerial desacolhendo 
a demanda "considerant que cet acte purament administratif ne peut constituer l'Etat débiteur envers le sieur Lucas." 8

\subsection{DA GÊNESE LEGISLATIVA}

Pois bem, a diversidade de condutas adotadas pelo Conselho de Estado para decidir as questões que lhes eram submetidas, qualificando de Ato Político as decisões que diziam respeito aos casos que envolviam pessoas das dinastias depostas; qualificando de Ato de Governo referindo-se ao autor do ato, ou seja, ao Governo como órgão do regime político existente; e, também, quando decidia admitindo a existência de Ato Diplomático, envolvendo interesses internacionais de pessoas ou coisas, foram fatores determinantes para que se concluísse pela impropriedade da Teoria do Móvel Político de natureza subjetiva e a substituísse pela teoria objetiva da Natureza do Ato.

Portanto, não mais os sujeitos, sim o ato em si, é que haveria de determinar a natureza da decisão do Conselho de Estado e, por força da lei de 24 de maio de 1872, que prescrevia que o Conselho de Estado haveria de resolver soberanamente sobre as demandas de anulação por excesso de poder interpostas contra os atos das diferentes autoridades administrativas, foi conferido ao mesmo Conselho o poder jurisdicional em toda sua amplitude. Essa justiça delegada permitiu que o Conselho de Estado apreciasse as questões que agora lhes eram submetidas, sem intervenção do Chefe de Estado, sujeitando a administração ao seu poder de decisão, o que resultou no surgimento do denominado Juge Administratif em contraposição ao Juge Judiciaire.

O marco desta nova etapa está no arresto Prince Napoleon, de 19 de fevereiro de 1875. Neste caso, o Prince Napoleon havia reclamado sua inclusão na lista de Generais de Divisão da Armada que por uma decisão ministerial o havia excluído. Desacolhida sua pretensão pelo Ministro da Guerra, Napoleão se dirige ao Conselho de Estado argüindo eivada de excesso de poder aquela decisão em seu desfavor, por falta de fundamento para anular uma situação que formalmente havia-lhe sido conferida por Decreto. A autoridade governamental apresentou ante o Conselho de Estado as suas razões de decidir e sustentou a irreversibilidade da decisão que "por sua forma, seu caráter, e pelas circunstâncias em que tinha sido tomada, constituía um ato de governo não suscetível de ser levado ao Conselho de Estado por excesso de poder, e 
não podia ser atacada pela via contenciosa ... por haver sido ditada por altas razões políticas." 9

Rompendo com a linha jurisprudencial precedente, o Conselho de Estado não só se declarou competente para conhecer do fundo da questão, como também desacolheu a aplicação do critério do Móvel Político do autor do ato para qualificá-lo como Ato de Governo.

Então, a par da origem jurisprudencial do Ato Político ou de Governo que se deu em dois momentos históricos como se viu, não se pode olvidar, por justiça, da sua gênese legislativa. Por este ângulo tem-se o artigo 26 da Lei de 24 de maio de 1872 que tem a seguinte redação:

Os ministros têm o direito de reivindicar do Tribunal de Conflitos os casos levados à seção do Contencioso e que não pertencem ao Contencioso-administrativo. Não podem ir a esta jurisdição antes que a seção do Contencioso haja resolvido fazer direito sobre a demanda de reivindicação que deve ser previamente comunicada. ${ }^{10}$

Esse texto legislativo é precedido do Decreto-Lei de 25 de março de 1852, e da Lei de 03 de março de 1849 que nele tem o seu artigo 47 reproduzido. ${ }^{11}$

O preâmbulo do Decreto-Lei supra referido ensejou, inclusive, a distinção entre Ato Político ou de Governo e Ato da Administração, por isso Ducrocq ensina que "a distinção entre atos de governo e administrativos não é somente conforme com a natureza das coisas, senão que resulta também do espírito e dos textos da legislação." ${ }^{12} \mathrm{E}$ não se olvide de que a fonte primeira e por excelência de Ato Político ou de Governo é a Lei Maior, a Constituição.

Carré de Malberg, por outra vertente, vê o Ato Político ou de Governo desde a Constituição francesa de 1791, não obstante citar como exemplos mais importantes de Atos Políticos ou de Governo as hipóteses contidas no artigo $8^{\circ}$ da Lei Constitucional de 16 de Julho de 1875 que diz respeito às atribuições do Presidente da República para negociar e ratificar os tratados internacionais. O que se extrai de sua reflexão é que nenhuma lei pode definir os limites objetivos, subjetivos e formais desses tratados, por isso que as suas cláusulas, os seus sujeitos e as suas formas são da exclusiva discricionariedade do Chefe do Poder Executivo. Tais elementos são constitutivos de poderes 
de governo distintos dos poderes da administração que autorizam atos administrativos delimitados por normas ordinárias. Acrescenta aos exemplares de Atos Políticos ou de Governo aqueles pelos quais, o Presidente da República exerce o direito de graça, também aqueles pelos quais faz a convocação das Câmaras e que decidem pela dissolução da Câmara dos Deputados, aqueles pelos quais nomeia funcionários, nomeia os seus ministros, enfim, todos os atos que pratica diretamente em razão da Constituição, não os que lhes são conferidos por leis ordinárias. ${ }^{13}$

Malberg, diverge dos que incluem a declaração do estado de sítio entre os Atos Políticos ou de Governo. Do seu ângulo o estado de sítio é um regime que resulta do direito comum e que tem como escopo impor aos cidadãos restrições ao exercício de suas liberdades ordinárias, por isso quando o Presidente da República declara o estado de sítio nos casos e sob as condições previamente estabelecidas na lei, está, tão e só, fazendo uso de um poder legal que consiste em um ato tipicamente executivo.

De outro ângulo coloca-se Rafael Bielsa ${ }^{14}$ que sustenta ser o estado de sitio a mais significativa atribuição do Poder Executivo na ordem política, visto as suas conseqüências consistentes na suspensão de certos direitos e garantias individuais.

Dissente ainda Malberg dos que incluem os atos do executivo relativos a polícia sanitária como se Políticos ou de Governo. Na sua ótica, os atos praticados pelo Presidente da República em época de epidemia têm fundamento em leis que o autorizam a prescrever, contra o perigo de contágio, todas as medidas de segurança que julgar necessárias, por isso são atos de administração e não Políticos ou de Governo.

O que distingue o Ato Político ou de Governo, na sua concepção, é, precisamente, a sua vinculação com a Lei Constitucional, porque o seu autor está livre de atenção aos preceitos legislativos ordinários e isto se dá em razão de uma potestade que é inerente ao Chefe do Poder, a ponto de admitir-se qualificar como titular de atividades independentes das leis.

Assim é que, segundo Jellinek ${ }^{15}$, há no Ato Político ou de Governo uma potestade autônoma que provém de uma concessão superior 
aos permissivos legislativos ordinários, e que, por conseguinte, não pode ser considerado como um poder executivo de leis, senão como um Poder de Governo. E arremata afirmando que "a fonte superior de onde provém este poder é a Constituição mesmo e não pode ser outra além dela. A teoria do ato de governo se refere diretamente à distinção entre a lei constitucional e as leis ordinárias."

A par da distinção que se faz de Ato Político ou de Governo e ato administrativo tomando-se por base a Lei Constitucional e a lei ordinária, tem-se também, nos moldes do direito positivo francês, sobretudo o artigo 26 da lei de 24 de maio de 1872, o fato de que o Ato Político ou de Governo não está sujeito a recursos contenciosos perante os tribunais.

O fato, contudo, dos Atos Políticos ou de Governo estarem a salvo de apreciação pelos tribunais não significa que a autoridade que os pratica possa tomar qualquer medida de modo inteiramente discricionário sob pretexto de A to Político ou de Governo. Pelo contrário, não pode realizar nenhum ato, mesmo sob a epígrafe de Político ou de Governo, sem que pela Constituição tenha sido autorizada tal prática. Este entendimento é coerente com o fundamento ideológico do modelo de Estado de Direito.

Assim, o Ato Político ou de Governo, por maior que seja o seu caráter discricionário, não se funda em um poder ilimitado, mas se realiza ao amparo de uma autorização constitucional especial relativa a objeto ou pessoa determinada, a circunstâncias especiais, e a uma categoria particular de atribuições. Portanto, elementos objetivos, subjetivos, circunstanciais e funcionais nele se identificam.

\subsection{DO DEBATE DOUTRINAL}

Encerradas estas fases de origem jurisprudencial e legislativa do Ato Político ou de Governo, tem-se que, a partir de então, desenvolveuse todo debate doutrinal em seu torno, compreendendo o período de 1875-1958, quando surgiram as teses positivistas e negativistas sobre o Ato Político ou de Governo.

Após 1958 inaugura-se um novo período sobre o Ato Político ou de Governo, agora movido por ideologias que trazem a marca do Segundo Pós-Guerra, que culmina com a doutrina atual quando se 
sobressaem as teses de Chapus, em que defende a união dos critérios subjetivo e objetivo para identificação do Ato Politico ou de Governo; de Capitant, com a natureza quase-legislativa do Ato Político ou de Governo; de Benoit, com o Ato Político ou de Governo como expressão da função governamental distinta da administrativa e em contraposição com a executiva; ${ }^{16}$ do Prof. Jorge Miranda, que insere o Ato Político ou de Governo dentre as funções do Estado que, segundo seu critério, são tripartidas em função legislativa, função administrativa e função jurisdicional. A função política, para o mesmo autor, é bipartida em função legislativa (lei) e função governativa ou stricto sensu (actos políticos ou de governo). Estes, a turno seu, são bipartidos em actos do povo activo e actos dos órgãos governativos. ${ }^{17}$

Certo é que a Teoria do Ato Político ou de Governo extrapola os limites geográficos da França para ser assimilado por vários países conforme as peculiaridades culturais, organizacionais e institucionais de cada qual.

Dentre os países que assimilaram a Teoria do Ato Político ou de Governo insere-se o Brasil que, por imposição de corte epistemológico, e para atender à temática destes estudos, somente nele se detém.

\section{O ATO POLÍTICO OU DE GOVERNO NO BRASIL E SUA JUDICIABILIDADE - DO DESCOBRIMENTO À REPÚBLICA}

Para melhor compreensão do Ato Político ou de Governo no Brasil e sua Judiciabilidade impõe-se contextualizá-lo na historicidade do Direito, mesmo que essa contextualização se faça aqui em epítome.

\subsection{PERÍODO COLONIAL}

A cronologia da História do Direito no Brasil pode compreender três grandes períodos. ${ }^{18}$ O primeiro deles, de 1500 (data do descobrimento) até 1808 (data da transferência da Corte Portuguesa para o Brasil), é denominado de Período Colonial. Neste período inserem-se seis sub-períodos seus compreendentes.

De 1500 até 1532, têm-se o primeiro sub-período quando se deu o alvorecer do Direito brasileiro, sendo o primeiro ato legislativo datado de 24 de janeiro de 1506, consistente de uma bula papal pela qual o 
Papa Julio II conferia a D. Manuel, na qualidade de Grão-Mestre da Ordem de Cristo e Rei de Portugal, os direitos sobre as terras do Brasil, em conseqüência do Tratado de Tordesilhas, celebrado em 1494 entre Portugal e Espanha, que estabelecia a linha de demarcação dos limites das conquistas de cada uma das referidas nações nas terras da América. Esta bula foi confirmada, posteriormente, por outra de 7 de junho de 1514, do Papa Leão X. Portanto, o primeiro ato legislativo foi de natureza eclesiástica.

Do elemento aborígena colhem-se um sistema de relação entre as tribos, uma noção rudimentar de propriedade, bem assim de constituição da família. Não obstante a aplicabilidade das Ordenações do Reino à realidade da nova Colônia força é convir que tal aplicação não se dava na sua integralidade visto as realidades díspares de um Brasil do século XVI e as leis e instituições já seculares de Portugal. Assim, as leis do Reino sofriam modificações para serem adaptadas às peculiaridades brasileiras.

O segundo sub-período, de 1532, (quando D. João III determinou a divisão do território brasileiro em Capitanias Hereditárias ou Donatárias) até 1548, inaugurando, desse modo, uma nova realidade exigente de regulações distintas no plano do Direito, a partir da juridicidade das próprias cartas de doação das Capitanias.

O terceiro sub-período, de 1549, (quando se deu, pela CartaRégia de 7 de janeiro de 1549, a delegação da autoridade do Rei a um Governador-Geral e fixando-se como sede desse Governo a Baía de Todos os Santos, instituindo desta feita uma outra realidade jurídica exigente, de igual modo, de regulação pelo Direito) e que perdurou até 1581 .

O quarto sub-período, de 1581, (quando se deu a dominação espanhola no Brasil, visto que a Espanha havia subjugado Portugal ao seu domínio e, com Portugal, o Brasil) dando-se desse modo início a uma nova realidade - com ênfase das Ordenações espanholas - que se estendeu até 1640 .

O quinto sub-período, o da Restauração, de 1640, (quando D. João IV subiu ao trono restaurando a dominação portuguesa, revalidando e confirmando as Ordenações Filipinas pela Lei de 29 de Janeiro de 1643) até 1750. 
O sexto e último sub-período que encerra o Período Colonial, estende-se de Pombal até à transferência da Corte Portuguesa para o Brasil e compreende os anos de 1750 a 1808, período coincidente com o engenho jurídico de Pascoal José de Mello Freire dos Reis (1738-1798), Manoel de Almeida e Souza Lobão (1745-1817), Joaquim José Caetano Pereira e Souza (1750-1818), que muito influenciaram a cultura jurídica do Brasil-Colônia. Não sendo possível menoscabar o trabalho do brasileiro José da Silva Lisboa, também conhecido por Visconde de Cairú, formado pela Universidade de Coimbra, que no final do século XVIII escreveu várias obras destacando-se os seus Princípios de Direito Mercantil e Leis da Marinha.

\subsection{PERÍODO IMPERIAL}

O segundo grande período da História do Direito no Brasil compreende quatro sub-períodos. O primeiro deles, de 1808 (fim da época Colonial) a 1822 (Proclamação da Independência). O segundo deles, de 1822 a 1831 (Primeiro Império). O terceiro deles, de 1831 a 1840 (Regência). O quarto deles, de 1840 a 1889 (Segundo Império).

\subsection{PERÍODO REPUBLICANO}

O terceiro grande período da História do Direito no Brasil, e é o que convém ao presente estudo, compreende dois sub-períodos. O primeiro deles, de 1889 a 1930. O segundo deles, de 1930 até a atualidade.

A abordagem do tema prescinde, é o que se vê, de tomada histórica que não compreenda um sistema Político-Democrático e Constitucional, por isso que a investigação sobre os Atos Políticos ou de Governo no Brasil e sua Judiciabilidade só se faz possível a partir do momento em que os poderes do Estado estejam constitucionalmente instituídos.

Portanto, somente a partir da Primeira República é que se identifica no Brasil a teoria dos Atos Políticos ou de Governo e sua Judiciabilidade, tempo imediatamente posterior ao seu surgimento em França.

Não se olvide, no entanto, que durante o Primeiro Império, por força da Constituição de 25 de Março de 1824, já se viam traçados, no plano teórico, os contornos do Ato Político ou de Governo, precisamente 
quando se fizeram normatizadas as atribuições do Imperador tanto no exercício do Poder Moderador (art. 101, incisos I a IX) - do célebre publicista Benjamin Constant sob inspiração de Clermont Tonnerre -, como no exercício do Poder Executivo (art. 102, incisos I a XV). Não há, contudo, notícia de sua judiciabilidade senão após 1892, Período Republicano, como se verá.

\section{O EVOLVER DO PENSAMENTO CONSTITUCIONAL NO BRASIL}

Ao findar, em 1815, o domínio napoleônico na Europa, viuse Portugal influenciado a elaborar um estatuto constitucional que o regesse e no qual se fizesse inserir um modelo de instituição política que mais bem atendesse os anseios de liberdade e segurança jurídica do seu povo.

Prevalecia em Portugal, como de resto nas demais nações da Europa, o regime político das monarquias de ênfase absolutista onde sobressaía o exercício de um único poder público que não comportava outra determinação que não fosse a do próprio Rei, então D. João I. As determinações, em formas de ordenanças, constituíam-se nas Ordenações do Reino.

Tem-se, pois, que no reinado de D. Afonso V (1438-1481) foram publicadas, em 1446, as Ordenações Afonsinas, divididas em títulos destinados à administração da justiça, à jurisdição da igreja, a forma do processo civil, ao direito civil e ao direito penal.

No reinado de D. Manoel I (1495-1521) fez-se uma revisão geral dessas Ordenações, com supressões e aditamentos, que foram publicados de 1512 a 1521, com a denominação de Ordenações Manuelinas.

No reinado de Filipe II (de Espanha), fez-se nova revisão do texto das Ordenações, que mais uma vez foram publicadas, agora, em 1603, com o título de Ordenações Filipinas.

Com a Restauração de 1640, que elevou ao trono de Portugal o Duque de Bragança, como D. João IV, foram confirmadas, em 1643, as Ordenações do Reino, que se constituíram no fundamento do Direito Civil português até a vigência do seu respectivo Código Civil, em 1868, 
promulgado que foi a $1^{\circ}$ de julho de 1867 , bem como se constituíram no fundamento do Direito Civil brasileiro, até 1918, quando vigorou o seu Código Civil.

Pois bem, retomando a reflexão histórica sobre o evolver do constitucionalismo no Brasil, tem-se que aos 24 de agosto de 1820, exsurge na cidade do Porto, em Portugal, um levante social exigindo a convocação da reunião das Cortes portuguesas ${ }^{19}$ com o fim de transformar a Monarquia Absoluta em um Regime Constitucional.

Fatores vários determinaram a propagação desse movimento que veio a culminar com a adoção do Regime Constitucional no Reino Unido de Portugal e Brasil, uma vez que este - o Brasil - já havia sido elevado à categoria de Reino Unido e de sede governamental da Monarquia bragantina. Constituiu-se, então, uma Junta Provisória de Governo quando foram convocados a nobreza, o clero e os representantes das cidades para, reunidos em Cortes, elaborarem, em definitivo, a Constituição Portuguesa.

Os acontecimentos políticos que se davam em Portugal repercutiam incontinenti no Brasil. Assim, no Pará, em $1^{\circ}$ de janeiro de 1821, deu-se um levante que substituiu o Governador e o Capitão-Geral por uma Junta Provisória presidida por D. Romuáldo Antonio de Seixas, que, em nome do povo do Pará, jurou fidelidade à Constituição que as Cortes de Portugal, em Lisboa, elaboravam. Quarenta e sete dias depois deu-se levante idêntico na Bahia que a título provisório adotou imediatamente a Constituição espanhola de 1812, e se fez intimação ao Rei D. João VI para que abandonasse as tradições arbitrárias do poder e se unisse a vontade do povo.

De resto, em 26 de fevereiro também de 1821, deu-se, no Rio de Janeiro, um movimento popular em que as tropas comandadas por Carreti, unidas com o povo sob a influência do discurso do Padre Macambôa, na praça hoje denominada Tiradentes, em atitude de sedição, ante a qual D. João VI, já no trono em razão do falecimento da rainha sua mãe em 1816, ordenou que o Príncipe Real D. Pedro desse conhecimento ao povo, de um Decreto, pelo qual era provisoriamente aprovado pelo Rei o Regime Constitucional. E à Constituição, mesmo em fase de elaboração, prestaram juramento de fidelidade os príncipes D. Pedro e D. Miguel em nome do rei D. João VI. 
Como os levantes populares não cessavam, o Rei apressou-se em determinar por Decreto, a adoção provisória, desde logo, em todo o Reino-Unido, da Constituição espanhola de 1812.

Sendo certo que o Brasil despertava no pensamento político português interesses divergentes, as Cortes determinaram que se fizesse retornar imediatamente para Lisboa a sede da Monarquia. Ante tal determinação, e sem poder resisti-la, retorna D. João VI para Portugal em fins de abril de 1821, levando consigo toda sua família, deixando no Rio de Janeiro apenas o seu filho mais velho, o Príncipe D. Pedro que, no dia 22 daquele mesmo mês, fora nomeado Regente do Reino do Brasil.

Estava D. João VI em Lisboa, no dia 5 de junho de 1821, quando prestou juramento às bases da Constituição portuguesa fazendo firmar e evoluir a novel concepção constitucionalista até que, em 5 de outubro de 1910, foi abolida a Monarquia e banida do território português a dinastia bragantina surgindo assim, em Portugal, a República Constitucional Representativa, Unitária e Parlamentar.

A crise surgida em Portugal com a importância que o Brasil se afigurava ter, muito especialmente em razão de sua elevação à categoria de Reino Unido, também em conseqüência da abertura dos seus portos às demais nações e, sobretudo, por ter se tornado sede do Governo de toda a nação luso-brasileira, provocou movimento reacionário no Brasil, que mais se fortaleceu quando se deu conta do propósito português de recolonizá-lo através das decretações feitas pelas Cortes, consistentes no parcelamento do Governo em províncias em tudo sujeitas às ordenações de Lisboa, na extinção dos tribunais do Rio de Janeiro e, por fim, na intransigente ordem de regresso à Portugal, do Príncipe Regente, cujas reações convergiram-se para o ideal de Independência.

O propósito de recolonização expresso inclusive na ordem de regresso à Lisboa feita ao Príncipe Regente resultou em uma tomada de posição da Junta Provincial de São Paulo, movida pelo engenho intelectual do Dr. José Bonifácio de Andrada e Silva, no sentido de convencer o Príncipe Regente a não atender às ordens das Cortes de Portugal e permanecer no Brasil a frente do Governo. No dia 9 de janeiro de 1822, chegou às mãos do Príncipe, através de José Clemente Pereira, um manifesto com milhares de assinaturas pedindo-lhe que 
permanecesse no Brasil. Desse manifesto resultou o histórico Dia do Fico.

Estava esboçada a Independência do Brasil que, a 7 de setembro do mesmo ano de 1822, foi proclamada definitivamente diante do fato do Príncipe D. Pedro receber terminantes ordens para regressar à Lisboa, e ter tido ciência de que as Cortes Portuguesas haviam revogado o Decreto pelo qual convocara uma reunião dos Procuradores Gerais das Províncias brasileiras.

Reafirma-se que o esboço da Independência estava de tal modo firmado após o 9 de janeiro de 1822 que, em 16 de fevereiro, o Dr. José Bonifácio de Andrada e Silva, Ministro do Príncipe Regente D. Pedro, fizera convocação a um Conselho de Procuradores Gerais das Províncias do Brasil, para se reunirem, no Rio de Janeiro, no dia 2 de junho também de 1822. Da reunião desse Conselho resultaria, como efetivamente resultou, a deliberação de convocação de uma Assembléia Geral de representantes das províncias. No dia 3 de junho, o Príncipe fez expedir Decreto convocando, para o Rio de Janeiro, a deliberada reunião que, conforme instruções de 19 do mês de junho, do Senhor Ministro José Bonifácio, se daria no dia 3 de maio de 1823 com um número de cem representantes. Essa Assembléia deveria visar a constituição de uma nação nova, com uma legislação de igual modo nova, em conformidade também com os costumes e os hábitos do povo do Brasil.

É certo então que o evolver do pensamento constitucional no Brasil teve início no movimento popular de 24 de agosto de 1820, na cidade do Porto, em Portugal.

Também é certo que o sentimento de luta por um novo regime político, aliado às influências dos ideais liberais de que tinham sido tomados os americanos e os franceses, a par do receio da recolonização, foram móveis determinantes para se chegar à Independência do novo Império do Brasil, que teria no príncipe D. Pedro o seu primeiro Imperador e defensor perpétuo, e se chegar, também, à convocação da aludida Assembléia que se converteu em Constituinte incumbida da elaboração de uma Constituição que regeria a vida do povo brasileiro, e que deveria nascer e se conduzir nos moldes de um regime Constitucional Representativo e de Forma Monárquica. 
As opiniões sobre o valor político dessa primeira Assembléia Nacional brasileira foram as mais divergentes e emergiram de dois grupos distintos de pessoas: dos brasileiros, que cada vez mais zelosos da sua terra e mais exigentes quanto à organização de seu governo; e dos portugueses, que cada vez menos conformados à nova condição de meros estrangeiros apenas domiciliados em uma nação distinta e menos dispostos a ceder aos seus antigos colonos a primazia política e social. Assim, em meio às divergências e também em meio às críticas veementes de um lado e apoio de outro, foi a Assembléia dissolvida, por Decreto do Imperador, em 12 de novembro de 1823.

A dissolução da Assembléia mais despertou o sentimento nacional de brasilidade marcando assim o início de uma dissensão desmedida dos brasileiros com o Monarca fazendo dai irromper a Revolução de 7 de abril de 1831, em que só foi possível a D. Pedro salvar o trono para seu filho, infante de cinco anos de idade, abdicando-lhe a coroa imperial e confiando-o à tutela de José Bonifácio de Andrada e Silva.

Sobre a dissolução da Assembléia, o historiador Armitage ${ }^{20}$ diz que, apesar da cáustica angústia, não mostraram os deputados fraqueza de ânimo, nem vacilação, tendo-se verificado que nem um abandonara a sua posição; o Deputado Drumond ${ }^{21}$, rigoroso crítico dos fatos e dos homens da época, diz em suas famosas Cartas, que todos acabaram nobremente; e dos próprios Anais da Constituinte, às páginas 247 do V volume, correspondente ao ano de 1823, consta que o respectivo Presidente, Maciel da Costa, depois Marques de Queluz, teria afirmado: "O que me dá grande satisfação, no meio de tudo, é ver a tranqüilidade da Assembléia [...]"

Aurelino Leal ${ }^{22}$, diz que "o golpe de Estado de 12 de novembro de 1823 foi favorável à evolução constitucional no Brasil."

Certo é que as manifestações dos brasileiros em favor dos constituintes forçou o Imperador a manter suas ações nos limites de um governo, que ele próprio, reconhecendo não poder ser mais absoluto e despótico, organizara Constitucionalmente e Liberal. E, de fato, passando o primeiro momento em que se buscou festejar a vitória do desfazimento da Assembléia, reconheceram logo, tanto o Imperador como os seus Conselheiros, que fora ela obtida à custa de um fatal rompimento entre o povo brasileiro e o Príncipe. 
Os desentendimentos vários, a par da revolução de Pernambuco que se unificara por quase todo norte, desde a Baia até o Ceará, fizeram com que D. Pedro admitisse que só poderia ser Imperador do Brasil dentro dos limites de uma organização constitucional franca e lealmente liberal.

Foi nesse contexto histórico que se deu a origem da Constituição de 25 de março de 1824, cuja elaboração o Imperador confiara, logo a 13 de novembro de 1823, a um Conselho constituído de dez membros, um dos quais era o próprio ex-presidente da dissolvida Constituinte, Maciel da Costa, mais tarde Marques de Queluz.

Fora expressa a promessa de que o novo projeto de Constituição seria observado atentamente, objeto de debate e modificado por uma nova Assembléia Constituinte, mas a inumerável medida de representações advindas das Câmaras das Províncias e da Capital aplaudindo, com grande maioria, o projeto imperial, que lhes fora, habilmente, submetido, influenciaram o Imperador a dispensar o confronto com uma nova Assembléia, que por certo lhe seria sobremodo desagradável.

\subsection{A CONSTITUIÇÃO POLÍTICA DO IMPÉRIO - 1824}

Então, aos 11 de março de 1824, firmou-se Decreto designando, impositivamente, o dia 25 do mesmo mês e ano para se fazer, no Rio de Janeiro, a solenidade de juramento de fidelidade à Constituição Política do Império, assim outorgada pelo Monarca, ao povo brasileiro, cuja decisiva soberania esse próprio estatuto reconhecia e afirmava. ${ }^{23}$

A Constituição de 1824 buscou reproduzir a concepção doutrinária dos constitucionalistas franceses Clermont-Tonerre e Benjamin Constant ${ }^{24}$ que distinguiam no poder conferido ao soberano, no regime Monárquico, duas atribuições distintas: a Executiva e a Moderadora. A primeira, de prerrogativas positivas, concedidas ao chefe do poder; a segunda, de tradicionais prerrogativas que faziam colocar os interesses do cidadão acima de rivalidades e paixões pessoais do governante. E não se pode mesmo ignorar que a instituição do Poder Moderador no regime monárquico mostrou-se conveniente, a ponto de poder-se admitir que também nos regimes constitucionais republicanos tem-se conferido ao Poder Judiciário atribuições moderadoras que vêm se apresentando imprescindíveis 
para o conveniente equilíbrio dos órgãos políticos nacionais frente aos interesses do cidadão e do povo.

Registre-se, contudo, que o Poder Moderador inserido na Carta de 1824, previa expressamente o seu exercício pelo Imperador, no caso D. Pedro II, que se houve, é bem de ver, de forma irrepreensível no exercício desse mister. No mais, a mesma Carta dispôs sobre os limites objetivos de sua atuação conferindo-lhe poderes para nomear os senadores; convocar a Assembléia Geral extraordinariamente nos intervalos das sessões quando assim o pedisse o bem do Império; sancionar os Decretos e Resoluções da Assembléia Geral para que tivessem força de Lei; aprovar e suspender interinamente as Resoluções dos Conselhos Provinciais; prorrogar ou adiar a Assembléia Geral e dissolver a Câmara dos Deputados nos casos em que o exigisse os interesses do Estado; nomear e demitir livremente os Ministros de Estado; suspender as atividades dos Magistrados; perdoar e moderar penas impostas aos réus condenados; conceder anistia em caso urgente, se assim aconselhassem a humanidade e o bem do Estado (art. 101, incisos I a IX da Constituição de 1824). Vê-se, já, um considerável elenco de Atos Políticos ou de Governo na própria Constituição de 1824, mas não se tem notícia da submissão de qualquer deles à apreciação dos tribunais.

Doutro passo, dispunha o artigo 102, incisos I a XV, da mesma Constituição, que ao Imperador tocava a chefia do Poder Executivo que seria exercido por seus Ministros de Estado, ao tempo em que dispunha sobre suas principais atribuições que consistiam em convocar a nova Assembléia Geral ordinária; nomear Bispos e prover os benefícios eclesiásticos; nomear Magistrados; prover os empregos civis e políticos; nomear os Comandantes das Forças de Terra e Mar, e removê-los se assim o pedissem os interesses da Nação; nomear Embaixadores e demais Agentes Diplomáticos e Comerciais; dirigir as negociações políticas com as nações estrangeiras; fazer tratados de aliança ofensiva e defensiva de subsídio e comércio, levando-os depois de concluídos à apreciação da Assembléia Geral quando o interesse e a segurança do Estado o permitissem; declarar a guerra e fazer a paz; conceder cartas de naturalização; conceder títulos, honras, ordens militares e distinções, em recompensa de serviços feitos ao Estado, dependendo as mercês pecuniárias de aprovação da Assembléia; 
expedir os Decretos, instruções e Regulamentos adequados à boa execução das leis; decretar a aplicação dos rendimentos destinados pela Assembléia aos vários ramos da Administração Pública; conceder ou negar o beneplácito aos Decretos dos Concílios e Letras Apostólicas e quaisquer outras Constituições Eclesiásticas que se não opuserem à Constituição; prover a tudo que for concernente à segurança interna e externa do Estado, na forma da Constituição. Do mesmo modo, outro elenco de Atos Políticos ou de Governo, sem que haja registro de apreciação de qualquer deles pelos tribunais.

Pela mesma Constituição foi mantido o Conselho de Estado que fora criado antes da proclamação da Independência quando o Príncipe Regente D. Pedro I, carecendo de fazer-se acompanhado de conselheiros que os auxiliassem com os seus conselhos, conferindo assim maior força moral aos seus atos, através do Decreto de 16 de fevereiro de 1822, criou o Conselho de Procuradores Gerais das Províncias, nomeados pelos próprios eleitores das paróquias, cujo Conselho tinha atribuições que foram vazadas nos seguintes termos: “1. Aconselhar-me todas as vezes que por mim lhe for mandado em todos os negócios mais importantes e difíceis. 2. Examinar os grandes projetos de reformas que se devam fazer na administração geral e particular do Estado, que lhe forem comunicados. 3. Propor-me as medidas que lhe parecerem mais urgentes e vantajosas ao bem do Reino Unido e à prosperidade do Brasil. 4. Advogar e zelar cada um dos seus membros pelas utilidades de sua Província respectiva."

A Assembléia Constituinte, por Carta de Lei de 20 de outubro de 1823, extinguiu o aludido Conselho afirmando que Procuradores das Províncias eram tão somente os seus respectivos Deputados em número fixado pela Constituição e que enquanto esta não criasse um Conselho do Imperador dever-se-ia admitir como Conselheiros de Estado, os Ministros.

Com a dissolução da Constituinte, em 12 de novembro de 1823, criou D. Pedro I, por Decreto de 13 de novembro de 1823, um Conselho de Estado, no qual deveriam ser tratados os negócios mais importantes, e especialmente deveria organizar-se o projeto de Constituição. Este Conselho de Estado compunha-se de dez membros, sendo que seis deles eram Ministros, por isso Conselheiros natos. 
Por fim, a Constituição, no seu Capítulo VII, criou o Conselho de Estado, nos seguintes termos:

Art. 137. Haverá um Conselho de Estado, composto de Conselheiros vitalícios, nomeados pelo Imperador. Art. 138. O seu número não excederá a dez. Art. 139. Não são compreendidos neste número os Ministros de Estado, nem estes serão reputados Conselheiros de Estado, sem especial nomeação do Imperador para este Cargo. Art. 140. Para ser Conselheiro de Estado requerem-se as mesmas qualidades que devem concorrer para ser Senador. Art. 141. Os Conselheiros de Estado, antes de tomarem posse, prestarão juramento nas mãos do Imperador de - manter a Religião Catholica Apostólica Romana; observar a Constituição, e as Leis; serem fieis ao Imperador; aconselhai-O segundo suas consciências, attendendo somente ao bem da Nação. Art. 142. Os Conselheiros serão ouvidos em todos os negócios graves, e medidas geraes da publica Administração; principalmente sobre a declaração de Guerra, ajuste de paz, negociações com as Nações Estrangeiras, assim como em todas as occasiões em que o Imperador se proponha exercer qualquer das attribuições próprias do Poder Moderador, indicadas no Art. 101, á excepção da VI. Art. 143 São responsáveis os Conselhos de Estado pelos conselhos, que derem, oppostos ás Leis, e ao interesse do Estado, manifestamente dolosos. Art. 144. O Príncipe Imperial, logo que tiver dezoito annos completos, será de Direito do Conselho de Estado: os demais Príncipes da Casa Imperial, para entrarem no Conselho de Estado ficam dependentes da nomeação do Imperador. Estes, e o Príncipe Imperial não entram no numero marcado no Art. 138." (In verbis).

Pois bem. Visto que tão somente ao Governo competia eqüilatar a gravidade e generalidade das medidas sobre as quais poderia ser ouvido o Conselho de Estado, resta certo que em boa parte de casos poderia deixar de ouvi-lo, por isso que nem todas as medidas administrativas têm caráter de gravidade e generalidade, como não têm a maior parte das questões contenciosas provenientes das reclamações das partes. Está visto então que não era esse Conselho uma Instituição, um Tribunal propriamente Administrativo. Era, sim, um órgão consultivo.

Devia, porém, ser necessariamente ouvido sobre a declaração de guerra, ajustes de paz, negociações com as nações estrangeiras, bem assim como em todas as ocasiões em que o Imperador se propusesse exercer quaisquer das atribuições do Poder Moderador. 
O Conselho de Estado foi suprimido pelo Ato Adicional de 7 de junho de 1834 que dispôs no seu art. 30: "Fica suprimido o Conselho de Estado, e serão eliminados da Constituição os artigos de que consta o Capítulo $7^{\circ}$ do Título $5^{\circ} .{ }^{\prime 25}$ Foi, contudo, posteriormente, revigorado pela Lei $\mathrm{n}^{\circ} 234$, de 29-11-1841.

\subsection{A CONSTITUIÇÃO DA REPÚBLICA - 1891}

Após mais de seis décadas de Monarquia, nas quais os ideais liberais progressistas foram se infiltrando nas camadas populares brasileiras, muito especialmente depois que a guerra com o Paraguai determinou maior aproximação com os nossos vizinhos do sul - desde a independência vivendo e prosperando sob o regime republicano - logrou uma minoria radical no Brasil, o apoio decisivo de duas classes distintas. A primeira, a dos plutocratas, uma minoria radical que ressentida com a ação altruística da herdeira do trono imperial frente à questão da abolição da escravatura no Brasil, fazendo-se assim redentora imortal dos escravos; a segunda, a dos militares, que se mostravam insatisfeitos com uma série de problemas que afetavam os ministros, especialmente após a grave enfermidade de que fora acometido D. Pedro II.

Embora tratarem-se de forças opósitas, foram elas dirigidas nesse momento histórico mais pelo ódio, em um mesmo sentido, tornandose fácil àquela minoria extremista explorar esse ódio, tanto mais brutal quanto inopinado, em proveito de uma repentina transformação radical do regime político. E essa transformação efetivou-se, aos 15 de novembro de 1889, com a substituição, pelo exército e pela armada nacionais, em nome da Nação, do Regime Monárquico pelo Regime Republicano Federativo, que seria organizado por futura Constituição. E, efetivamente, após pouco mais de um ano de Governo Provisório, foi promulgada, aos 24 de fevereiro de 1891, a primeira Constituição Republicana do Brasil.

Com o início do Período Republicano, suprime-se o Poder Moderador e a jurisdição administrativa antes atribuída ao Conselho de Estado. Isto ocorreu porque se abandonou a influência francesa da dualidade de jurisdição e se acolheu o modelo anglo-americano da unidade de jurisdição.

É natural que se associe a temática - Atos Políticos ou de Governo e 
sua Judiciabilidade - com as noções de Democracia e Constitucionalismo, até porque o princípio da separação dos poderes como fundamento do Ato Político ou de Governo constituiu-se na tese de Ducrocq e na segunda formulação da teoria de Hauriou $^{26}$.

Não obstante tratarem-se, Democracia e Constitucionalismo, de figuras jurídicas de natureza político-democráticas distintas, elas se mostram interdependentes por isso que não é possível a Democracia senão na forma Constitucional.

A Democracia ${ }^{27}$ tem como ênfase o poder exercido através da maioria do povo, enquanto que o Constitucionalismo tem como ênfase a separação dos poderes com os limites de atuação de cada qual previamente estabelecidos sempre com vistas na proteção dos direitos e das garantias do cidadão. Em verdade não se contrapõem, não obstante dessemelhantes os fundamentos que os justificam e os explicam. Assim é que, historicamente, busca-se identificar sistemas de permitir a coexistência dessas duas concepções políticodemocráticas.

Pelas constituições flexíveis prevalecem os sistemas democráticos em que a vontade da maioria, expressa através de seus representantes, não sofre limitação ou restrição por parte de qualquer Poder. Quem não foi eleito pelo povo não tem legitimidade para traçar nem ditar normas aos seus representantes diretos. Nesse modelo insere-se o sistema britânico de constituição flexível.

Nos sistemas de constituições rígidas sobressaem-se o texto constitucional como expressão de deliberação do povo através de uma assembléia constituinte com caráter vinculativo, bem como as deliberações ordinárias, tanto do Legislativo quanto do Executivo, que devem ser, por seu turno, harmônicas com o texto constitucional, cabendo aos tribunais a tarefa fiscalizadora dessa harmonização. Em caso de desarmonia cabe aos tribunais medida de sobrestamento da deliberação, quer do Legislativo, quer do Executivo, o que se fará por provocação através de ação própria.

Nos sistemas de constituições semi-rígidas, quais as que admitem no mesmo texto constitucional cláusulas rígidas e flexíveis, como foi o caso da constituição brasileira de 1824 que estabelecia em seu artigo 178 o seguinte: “É só constitucional o que diz respeito aos limites e 
atribuições respectivas dos poderes políticos e aos direitos políticos e individuais dos cidadãos. Tudo que não é constitucional pode ser alterado sem as formalidades referidas pelas legislaturas ordinárias". Vê-se uma bipartição entre dispositivos materiais e dispositivos formais apresentando-se aqueles em posição hierarquicamente superior a estes.

Por fim, pode-se anotar um modelo constitucional em que determinadas cláusulas lançadas nas constituições não sãoflexíveis, não são rígidas, não são semi-rígidas, mas são super-rígidas. Nestas, existem cláusulas asseguradoras de determinados direitos fundamentais que não se derrogam. Tais direitos precedem à existência do Estado e não estão sujeitos a modificações mesmo que por deliberação majoritária. A idéia das normas supra-constitucionais reguladoras de determinados direitos surgiu com a derrocada do totalitarismo europeu sobretudo na segunda metade do século passado com vistas na proteção dos direitos à vida, à liberdade, à propriedade e à segurança jurídica.

Impõe-se o registro das chamadas constituições dirigentes que, a par de prescreverem as comuns atribuições de um Estado Liberal criam condições de realização de uma justiça social e econômica marcando o surgimento de um novel modelo de Estado do Bem Estar Social.

Com efeito, após a Constituição de 1891, se instaurou o Estado Liberal de Direito e com a Constituição de 1934 pôde-se falar em Estado Social de Direito. Cuidava-se de assimilar o modelo de um Estado prestador de serviços, que foi ampliando a sua atuação na vida econômica e social, com repercussão na Constituição de 1988 que, por seu turno, agasalhou os princípios próprios do Estado Democrático de Direito, referidos a partir do seu preâmbulo.

\subsection{HISTÓRICO E PECULIARIDADES DOS FATOS DETERMINANTES DOS PRIMEIROS ATOS POLÍTICOS OU DE GOVERNO LEVADOS À APRECIAÇÃO DO PODER JUDICIÁRIO NO BRASIL}

Embora a Constituição de 1891 previsse no seu artigo 47 que o Presidente e o Vice-Presidente da República seriam eleitos por sufrágio direto da Nação, e maioria absoluta de votos, também 
previu no artigo $1^{\circ}$ das suas Disposições Transitórias que, após promulgada a Constituição, o Congresso, reunido em assembléia geral, elegeria por maioria absoluta de votos, na primeira votação, e, se nenhum candidato obtivesse maioria absoluta, na segunda votação por maioria relativa de votos, o Presidente e o Vice-Presidente dos Estados Unidos do Brasil.

Então, candidataram-se ao cargo de Presidente o Marechal Deodoro da Fonseca e o Presidente do Congresso Prudente de Morais; à Vice-Presidência candidataram-se - porque as chapas eram distintas - o ex-ministro da Marinha, Almirante Eduardo Wandenkolk e o exministro da Guerra, Marechal Floriano Peixoto. Foram vitoriosas as chapas dos marechais Deodoro da Fonseca e Floriano Peixoto, embora a votação de seus concorrentes demonstrasse a existência de uma ponderável força política contrária. A oposição ao Marechal Deodoro da Fonseca formara-se durante o Governo Provisório, chegando mesmo a transformar-se em séria dissidência entre aqueles que haviam criado o novo regime. Acusavam-no, inclusive, de defensor da monarquia, não tendo ele, no entanto, demonstrado interesse em restaurá-la.

Habituado à disciplina de quartel, uma vez que filho do militar alagoano Manuel Mendes da Fonseca Galvão, Deodoro da Fonseca matriculou-se, em 1843, na Escola Militar do Rio de Janeiro e formouse no Curso de Artilharia em 1847. No ano seguinte, combateu a Revolução Praieira em Pernambuco.

Participou da Guerra do Paraguai (1865-1870), sendo ferido nas batalhas de Angustura e Itororó. Em 1868, chegou ao posto de Coronel. Em 1874, ao posto de Brigadeiro e, em 1884, foi promovido ao posto de Marechal-de-Campo. Em 1885, foi nomeado Comandantede-Armas do Rio Grande do Sul, alcançando, ao depois, o cargo de Presidente dessa Província.

No posto de Presidente da Província do Rio Grande do Sul envolveu-se na Questão Militar que consistiu no confronto com o Presidente do Conselho de Ministros, o Barão de Cotegipe, e com o próprio Imperador D. Pedro II. Mas, no fim, foi exonerado do cargo.

Quando do seu retorno ao Rio de Janeiro, em 1887, tornou-se presidente do Clube Militar e negou-se a perseguir escravos fugitivos. 
Como forma de afastá-lo da política, foi nomeado para o Comando Militar do Mato Grosso pelo Visconde de Ouro Preto, na época, 1888, Presidente do Conselho de Ministros.

Inconformado com as atitudes do Governo Imperial, abandonou o Comando em meados de 1889 e voltou para o Rio de Janeiro. Mesmo sendo monarquista aderiu ao movimento republicano e liderou o golpe militar que depôs o Visconde de Ouro Preto e acabou com a monarquia no Brasil, instaurando o regime republicano.

Como chefe do Governo Provisório Republicano, Deodoro da Fonseca convocou a Assembléia Constituinte que acabou por aprovar a primeira Constituição Republicana em 24 de fevereiro de 1891, resultado de um projeto apresentado por uma comissão de cinco juristas nomeados pelo Governo Provisório e constituída dos Senhores Joaquim Saldanha Marinho - Presidente; Américo Brasiliense de Almeida Melo - Vice-Presidente; e mais, Antônio Luís dos Santos Werneck, Francisco Rangel Pestana e José Antônio Pedreira de Magalhães Castro. Este projeto teve a redação de Rui Barbosa que, não obstante afirmar-se monarquista, não se opunha ao modelo republicano desde que os poderes executivo e legislativo fossem equilibrados pelo judiciário. Temia Rui Barbosa que sem esse equilíbrio o presidencialismo "tornar-se-ia o mais tirânico dos sistemas, com a agravante de substituir a responsabilidade moral e perpétua das famílias reinantes pela irresponsabilidade de ditadores transitórios de quatro anos." 28

Os nove meses em que o Marechal Deodoro da Fonseca esteve na Presidência da República foram de desentendimentos com os parlamentares civis, em sua maior parte representantes dos latifundiários brasileiros. Ressentido com a falta de apoio parlamentar, em 3 de novembro de 1891 dissolvia o Congresso, não obstante não ter poderes constitucionais para tanto e, confiado no Exército, declarava estado de sítio. ${ }^{29}$

Foi precisamente em razão da crise que se estabeleceu antes da declaração do estado de sítio e no seu pós imediato que, pela primeira vez na história do direito brasileiro falou-se em Ato Político ou de Governo e na sua Judiciabilidade. E tal se deu, outrossim, através de Rui Barbosa que não só exerceu grande influência na formação das instituições jurídicas reconhecidas e afirmadas pela primeira 
Constituição Republicana, como, a seu par, exerceu igual influência na interpretação dos textos nela contidos.

Tem-se então que foi no apogeu da crise política reinante que o Congresso, através de moção, investiu o Presidente da República "em poderes extraordinários" ficando autorizado a fazer uso das medidas mais enérgicas para assegurar a ordem na novel República.

A moção, aprovada pelo Congresso em 21 de janeiro de 1892, traz em síntese - no que convém ao presente estudo - o seguinte texto: “O Senado e a Câmara resolvem dar por terminados os trabalhos da presente sessão extraordinária, esperando do governo, em quem amplamente confia, e que se acha forte pelo apoio de toda nação, o emprego de todos os meios, mesmo os mais enérgicos, que as circunstâncias aconselhem, a fim de manter a ordem, punir severamente os que tentarem, ou vierem a tentar, perturbar a paz e a tranqüilidade pública, restabelecer o regime verdadeiramente federativo, conspurcado pelo ato de 3 de novembro, e consolidar a República."

Assim, firmado nessa delegação, o Presidente da República, em 7 de abril de 1892 reformou, compulsoriamente, por Decreto, sob alegação de "inconveniente espírito de indisciplina, procurando plantar a anarquia no momento crítico da reorganização da pátria e da consolidação das Constituições republicanas", o Vice-Almirante Eduardo Wandenkolk; os Contra-Almirantes José Marques Guimarães e Dionysio Manhães Barreto; o Marechal José de Almeida Barreto; os Generais de Divisão Candido Costa, Antonio Maria Coelho e José Clarindo de Queiroz; os Generais de Brigada José de Cerqueira Aguiar Lima e João Nepomuceno de Medeiros Mallet; o General de Brigada João Luiz de Andrade Vasconcellos; o General de Brigada Dr. João Severiano da Fonseca.

Em12 de abril de1892, ainda por Decreto, foram compulsoriamente reformados os Capitães-Tenentes Duarte Huet de Bacellar Pinto Guedes, José Gonçalves Leite e João Nepomuceno Baptista; bem como os Primeiros Tenentes João da Silva Retumba, Bento José Manso Sayão e José Libanio Lamenha Lins de Sousa, todos da Armada Nacional; e do Exército, do corpo de engenheiros, o Tenente-Coronel do quadro extranumerário Gregório Thaumaturgo de Azevedo; do corpo de Estado-Maior de primeira classe, o Coronel do quadro extranumerário João Soares Neiva, Capitão Felisberto Piá de Andrade; 
da repartição sanitária, o Tenente-Coronel, médico de $2^{a}$ classe, Dr. Antonio Pinheiro Guedes; da Arma de Artilharia, o $2^{\circ}$ Tenente do quadro extranumerário Domingos Jesuíno de Albuquerque; da Arma de Cavalaria o Major-Fiscal Sebastião Bandeira, o Capitão Gentil Eloy de Figueiredo, o Tenente Coronel Comandante Antonio Adolpho da Fontoura Menna Barreto, e o Capitão Modestino Roquette; da Arma de Infantaria, o Coronel agregado Antonio Carlos da Silva Piragibe, o alferes Alfredo Martins Pereira, o alferes Carlos Jansen Junior, e o Capitão Manoel Raymundo de Souza.

A par dos militares reformados, também, por Decreto, de 12 de abril de 1892, foram demitidos do Magistério Superior, o Dr. Arthur Fernandes Campos da Paz, Lente Catedrático da $1^{a}$ Seção da Faculdade de Medicina da cidade do Rio de Janeiro, e o Dr. José Joaquim Seabra, Lente Catedrático da $2^{\mathrm{a}}$ Cadeira da $2^{\mathrm{a}}$ Série do Curso de Ciências Sociais da Faculdade de Direito de Pernambuco. Os demitidos, nas funções catedráticas que exerciam, eram inamovíveis ou vitalícios por força do Decreto $\mathrm{n}^{\mathrm{o}} 1232 \mathrm{H}$, de 2 de janeiro de 1892, que no seu artigo 55 prescrevia: “Os lentes catedráticos e substitutos são vitalícios desde a data da posse." Isso relativo ao Magistério nas Faculdades de Direito. Quanto ao Magistério nas Faculdades de Medicina, o Decreto ${ }^{\circ}$ 1270, de 10 de janeiro de 1891, dispunha no seu artigo 41 que: "O membro do magistério é vitalício." 30

Registre-se que os casos aqui nominados dizem respeito aos que foram objetos de defesa do Advogado Rui Barbosa, perante a Justiça Federal, através de ações de reparação civil em face da Nação, pelos atos praticados pelo seu Representante Maior, ditos já à época Atos Políticos ou Atos de Governo praticados em momentos e situações especiais com vistas, em tese, na defesa de interesses nacionais. É certo, é bem de ver, que outros casos similares existiram.

A judiciabilidade de tais atos foi sustentada, fundamentadamente, por Rui Barbosa, com base no modelo constitucional brasileiro assimilado que se fez do modelo Americano do Norte que se distinguiu por "um profundo apego à liberdade individual e uma desconfiança invencível contra todo poder, fosse qual fosse". Questionava Rui Barbosa tanto a validade da moção do Congresso Nacional ao Presidente, bem assim os demais atos do Executivo, à parte a moção, e que eram contrários aos textos da Constituição. 
Na concepção americana a soberania é inalienável, os deputados exercem apenas um poder subalterno e derivado e não lhes cabe exceder o mandato que lhes foi conferido. Esse mandato é a Constituição de onde se extrai que o povo é o verdadeiro soberano e seu outorgante.

Afirmou o Juiz Paterson, ${ }^{31}$ no Estado de Filadélfia.

A Constituição é a lei suprema; sua dignidade prevalece à da legislatura; só a autoridade, que a fez, poderá mudá-la; o Poder Legislativo é criatura da Constituição; deve à Constituição o existir; recebe os seus poderes da Constituição; e, pois, se os atos dele não conformam com ela, são nulos.

A invalidade da ação dos poderes políticos fora dos círculos dos textos constitucionais é o dogma cardeal do constitucionalismo americano. A evolução lógica desse dogma foi traçada por Marshall ${ }^{32}$, o supremo expositor da Constituição americana, nos seguintes termos:

Toda a construção do direito americano tem por base a noção de que o povo possui originariamente o direito de estabelecer, para o seu futuro governo, os princípios, que mais conducentes se lhe afigurem à sua utilidade. O exercício desse direito original é um insigne esforço: não pode, nem deve repetir-se freqüentemente. Os princípios, que destarte uma vez se estabeleceram, consideram-se, portanto, fundamentais. E, como a autoridade, de que eles dimanam, é suprema, e raro se exerce, esses princípios têm destino permanente. A vontade primitiva e soberana organiza o governo, assinando-lhe os diferentes ramos, as respectivas funções. A isto pode cingir-se; ou pode estabelecer raias, que eles não devam transpor. Nesta última espécie se classifica o governo dos Estados Unidos.

\section{Continua:}

Definiram-se e demarcaram-se os poderes da legislatura; e, para que sobre tais limites não ocorressem erros, fez-se escrita a Constituição. Com que fim se estipulariam esses poderes, e com que fim se reduziria essa estipulação a escrito, se os limites prescritos pudessem ser ultrapassados exatamente por aqueles que ela se propunha coibir? Acabou-se a distinção entre governos de poderes limitados e os de poderes indefinidos, se os confins, que se estabelecem, não circunscreverem as pessoas, a que se impõem, e ficarem igualmente 
obrigatórios os atos permitidos e os atos proibidos. Ou havemos de admitir que a Constituição anula qualquer medida legislativa, que a contrarie, ou anuir em que a legislatura possa alterar por medidas ordinárias a Constituição.

A Magistratura de Virgínia, em 1782, afirmava nulo, porque antagônico ao pensamento da Constituição, um ato da Assembléia do Estado que, dois anos antes, avocara à legislatura a prerrogativa de agraciar. E, sustentando Edmundo Randolph que, conforme, ou contraria, à Constituição, a lei era igualmente obrigatória para os juízes, o presidente do tribunal redargüiu-lhe nestas palavras memoráveis:

Ainda quando a legislatura inteira tente saltar os limites, que o povo lhe traçou, eu, administrando a justiça pública deste país, concentrarei a autoridade investida nesta cadeira, e, apontando à Constituição, direi aos legisladores: "Aqui estão os confins de vosso poder: daqui não passareis." 33

Quanto ao Executivo, tem-se do constitucionalista Marshall o seguinte texto:

Se o presidente excede a sua autoridade, ou usurpa a de um dos outros ramos do governo, suas ordens, instruções, ou decretos não protegem a ninguém, e os agentes, que as executarem, ficam pessoalmente responsáveis por seus atos. $\mathrm{O}$ freio dos tribunais consiste, pois, na faculdade que lhes pertence, de manter o executivo dentro na esfera de sua autoridade, recusando sanção jurídica a qualquer ato, a que ele fora dele se aventure.

Os poderes republicanos são mandatários da nação soberana dentro no terreno das faculdades que a Constituição lhes traça. Na Constituição está o instrumento do mandato que lhes limita o perímetro legítimo de ação. Ela é parte essencial de cada lei e de cada ato administrativo "tanto quanto uma procuração o é da escritura celebrada em nome da autoridade que ela confere." Todo arbítrio exercido além desse termo é vão e inútil como os atos do falso procurador.

Daí tem-se o suporte da Constituição Republicana do Brasil identificado na supremacia das disposições dos seus textos sobre 
as demais leis, bem assim na limitação dos poderes legislativo e executivo, fazendo com isso impenetráveis as muralhas que protegem os direitos e as garantias individuais.

Cabendo distinguir aqui, com Rui Barbosa, os direitos das garantias.

Os direitos são aspectos, manifestações da personalidadehumana em sua existência subjetiva, ou nas suas situações de relação com a sociedade, ou os indivíduos, que a compõem. As garantias constitucionais stricto sensu são as solenidades tutelares, de que a lei circunda alguns desses direitos contra os abusos do poder. ${ }^{34}$

Quando pois, o Ato Político ou de Governo, afeta direitos assegurados pela Constituição, não se questiona a sua judiciabilidade. Ei-la plenamente possível. No caso de Rui Barbosa, tem-se a sua tese assentada em que a declaração do estado de sítio determina a suspensão temporária das garantias, sem qualquer afetação dos direitos, como bem expressa o artigo 80 da Constituição Federal de 1891: "Poder-se-á declarar em estado de sítio qualquer parte do território da União, suspendendo-se aí as garantias constitucionais por tempo determinado, quando a segurança da Republica o exigir, era caso de agressão estrangeira, ou comoção intestina (art. 34, $\mathrm{n}^{\circ}$ 21)." O $\$ 1^{\circ}$ deste artigo tem a seguinte redação: “Não se achando reunido o Congresso, e correndo a Pátria iminente perigo, exercerá essa atribuição o Poder Executivo Federal (art. 48, n 15)."

Se o Congresso tivesse a faculdade de atribuir ao Executivo poderes para suprir, a pretexto do estado de sítio, a vitaliciedade assegurada pela Constituição às funções inamovíveis, pela mesma razão teria a de suspender, durante o estado de sítio, todos os outros direitos, enumerados na declaração geral deles.

Conforme a Constituição de 1891 o estado de sítio era atribuição do Congresso Nacional. É o que se lê no seu artigo $34 n^{\circ} 21$ :

Compete privativamente ao Congresso Nacional: ... 21. Declarar em estado de sítio um ou mais pontos do território nacional, na emergência de agressão por forças estrangeiras ou de comoção interna, e aprovar ou suspender o sítio que houver sido declarado pelo Poder Executivo, ou seus agentes responsáveis, na ausência do Congresso. 
Não se achando, porém, reunido o Congresso, e correndo a Pátria iminente perigo, exercerá essa atribuição o Poder Executivo Federal. Nesta hipótese, contudo, a Constituição determina a natureza das medidas de repressão que podem ser usadas. E as medidas expressamente previstas na Carta Maior eram detenção e desterro.

Tem-se, pois, e foi o que ficou assentado ao tempo de Rui Barbosa, que mesmo os Atos Políticos ou de Governo não podem deixar de estar ao amparo da Constituição Federal, porque, se ao desabrigo estiverem, e se deles decorrerem afetação a direitos individuais dos cidadãos, reafirma-se, a sua judiciabilidade sobressai inquestionável.

Por certo que as questões levantadas por Rui Barbosa tornaramse em centro de atenção dos Constituintes seguintes como se vê na imediata Constituição de 1934 que no seu artigo 68 estabeleceu: "É vedado ao Poder Judiciário conhecer de questões exclusivamente políticas."

De resto, vê-se que o Legislador Constituinte, em estados excepcionais, teve o cuidado de se prevenir, expressamente, quanto às situações que foram objeto de apreciação judicial em 1892.

Assim, quando da elaboração do Ato Institucional $n^{0}$ 5, de 13 de dezembro de 1968, assentou-se precisamente o que Rui Barbosa levou à apreciação do Poder Judiciário do seu tempo. $\mathrm{O}$ artigo $6^{\circ}$ do Ato Institucional $n^{\circ} 5$ estabeleceu: “Ficam suspensas as garantias constitucionais ou legais de, vitaliciedade, inamovibilidade e estabilidade, bem como a de exercício em funções por prazo certo."

$\mathrm{O} \S 1^{\circ}$ do mesmo artigo foi assim redigido:

O Presidente da República poderá, mediante decreto, demitir, remover, aposentar ou pôr em disponibilidade quaisquer titulares das garantias referidas neste artigo, assim como empregados de autarquias, empresas públicas ou sociedades de economia mista, e, demitir, transferir para a reserva ou reformar militares ou membros das polícias militares, assegurados, quando for o caso, os vencimentos e vantagens proporcionais ao tempo de serviço.

Vê-se que mesmo em se tratando de regime de exceção impõe-se seja, em primeiro, afastada a supremacia da Constituição para que se possam praticar Atos Políticos ou de Governo a salvo da possibilidade 
de sua apreciação pelo Poder Judiciário, ou seja, a salvo de sua judiciabilidade, havendo possibilidade de se prever expressamente hipóteses que não tocam ao Poder Judiciário apreciar atos do Executivo. Assim ocorreu também com o Ato Institucional $\mathrm{n}^{\circ} 5$, de 13 de dezembro de 1968, quando no seu Art. $5^{\circ}$, parágrafo $2^{\circ}$, sobre suspensão de direitos políticos, estabeleceu: “§ $2^{\circ}$ - As medidas de segurança de que trata o item IV deste artigo serão aplicadas pelo Ministro de Estado da Justiça, defesa a apreciação do seu ato pelo Poder Judiciário". (grifo nosso).

\subsection{A CONSTITUIÇÃO DE 1934}

A Constituição de 1934, no seu artigo 68, previa que: “É vedado ao poder judiciário conhecer de questões exclusivamente políticas" ${ }^{35}$. Estava assim, o direito positivo brasileiro traçando nitidamente os contornos do A to Político ou de Governo e agora da sua não judiciabilidade.

\subsection{AS CONSTITUIÇÕES DE 1891, 1937, 1946, 1967, 1969 E 1988}

As Constituições de 1891 (Republicana), 1937, 1946, 1967, 1969 e 1988, não fizeram referência expressa à proibição da judiciabilidade do Atos Políticos ou de Governo pelo Poder Judiciário, como se deu com a Constituição de 1934.

Mas tal proibição, a rigor, não existe no Direito brasileiro, pois é conseqüência natural e direta da própria natureza do regime, o que sempre foi afirmado pela doutrina e reiterado pelas decisões dos tribunais.

Aliás, o próprio Rui Barbosa ${ }^{36}$ já defendia a desnecessidade dessa previsão expressa em texto Constitucional.

Esta competência dos tribunais, porém, como se vê, não resulta de cláusulas expressas que positivamente a declarem.

Nem as constituições locais, nem a dos Estados Unidos contêm artigo que prescreva a autoridade judiciária não aplicar as leis inconstitucionais. Nenhum texto explícito e formal a investe nessa prerrogativa tão importante: o juiz a possui implicitamente, como parte integrante de suas atribuições. 


\section{DA JUDICIABILIDADE DOS ATOS POLÍTICOS OU DE GOVERNO NO BRASIL}

O que se tem por certo no ordenamento jurídico vigente no Brasil é que o A to Político ou de Governo é suscetível de apreciação judicial, ou seja, quando a ação dos poderes governamentais, no exercício de suas atribuições constitucionais, ameaçar e lesar os direitos individuais, não se questiona a possibilidade de tais ações serem submetidas a apreciação do Poder Judiciário e por este revistas.

Nesse sentido é que se conduz toda doutrina brasileira admitindo que o Ato Político ou de Governo é judicializável na medida em que seja praticado contrariamente aos preceitos constitucionais.

Os Atos Políticos ou de Governo situam-se em um campo discricionário quanto as circunstâncias determinadoras de sua prática, quanto aos sujeitos que por ele devem ser alcançados, quanto ao seu conteúdo e quanto ao tempo de sua duração. Então, elementos sociais e políticos, subjetivos, objetivos e temporais são seus determinantes. Mas em nenhuma hipótese admite-se a sua prática sem que haja estatuído a Constituição sobre a possibilidade de fazê-lo. É como que se o constituinte deixasse ao Chefe do Poder conceitos abertos e até indeterminados em um plano abstrato e genérico para que em cada situação fática e concreta se operasse a integração da norma. É uma discricionariedade que tem, previamente, um comando legal que a autoriza.

Impõe-se ao Chefe do Poder, na prática do Ato Político ou de Governo, não se olvidar dos limites traçados pela Ordem Política e Jurídica da Sociedade a que se destina.

Os Atos Políticos ou de Governo são, pois, aqueles praticados não ordinariamente em cumprimento das leis ordinárias. Sim, situamse em um plano extraordinário, sempre com vistas na defesa dos interesses das razões de Estado, mas, jamais, afetando direitos individuais já adquiridos pelos cidadãos ou afetando interesses públicos.

\section{POSIÇÃO DA DOUTRINA BRASILEIRA}

A doutrina brasileira, tanto da parte de Celso Antônio Bandeira 
de Mello, como da parte de Hely Lopes Meirelles, também de Maria Sylvia Zanella Di Pietro, tem sido unívoca em admitir o Ato Político ou de Governo desde que nos limites traçados pela Constituição e, caso assim não seja, faz-se inquestionável a possibilidade de ser levado à apreciação pelo Poder Judiciário.

Da parte de Di Pietro ${ }^{37}$ colhe-se o seguinte ensinamento:

Com relação aos atos políticos, é possível também a sua apreciação pelo Poder Judiciário, desde que causem lesão a direitos individuais ou coletivos. Houve um período no direito brasileiro, na vigência da Constituição de 1937, em que os atos políticos eram insuscetíveis de apreciação judicial, por força de seu artigo 94. Essa norma ligava-se à concepção do ato político como sendo aquele que diz respeito a interesses superiores da nação, não afetando direitos individuais; como o exercício do direito de ação estava condicionado à existência de um direito individual lesado, não ocorrendo essa lesão, faltava o interesse de agir para o recurso às vias judiciais.

A exclusão da apreciação judicial do Ato Político ou de Governo expressa nos termos da Constituição de 1937 situa-se em um plano consequencial excludente da possibilidade de acesso à jurisdição. Pelo que dispôs o artigo 94 da aludida Carta não se afastava a possibilidade da prática do Ato Político ou de Governo mas sim o direito de ação dele decorrente caso comprometesse direitos individuais.

Doutro passo, tem-se no regime de exceção, como se vê no Ato Institucional $\mathrm{n}^{\circ}$ 5, de 13 de dezembro de 1968, expressamente previsto a possibilidade do Presidente da República praticar Atos Políticos que, em tempo de normalidade, seriam tidos como ofensivos aos direitos dos cidadãos por isso que em desacordo com a melhor construção ideária do modelo de Estado Constitucional, Democrático e de Direito.

A par da previsão de possibilidade da prática de Atos Políticos ou de Governo contrários à boa fisiologia do Estado Constitucional, Democrático e de Direito, expressamente ainda previu o mesmo Ato Institucional, no seu artigo 11, a não judiciabilidade dos tais Atos praticados pelo Presidente da República. "Art. 11: Excluem-se de qualquer apreciação judicial todos os atos praticados de acordo com este Ato Institucional e seus Atos Complementares, bem como os respectivos efeitos". 
Bandeira de Mello, ${ }^{38}$ diz que Atos Políticos ou de Governo são aqueles praticados pela Administração Pública "com margem de discrição e diretamente em obediência à Constituição, no exercício de função puramente política, tais o indulto, a iniciativa de lei pelo Executivo, sua sanção ou veto, sub color, de que é contrária ao interesse público, etc."

Lopes Meirelles ${ }^{39}$, por seu turno, já chegou a admitir a insuscetibilidade de apreciação judicial do Ato Político ou de Governo, conforme sua própria asserção no sentido de que

Essa peculiaridade tem conduzido a maioria dos autores a considerálos insuscetíveis de apreciação judicial - e nós mesmos já incidimos nesse equívoco em edições anteriores -, o que não é exato, porque, na realidade, a Justiça os aprecia, apenas com maiores restrições quanto aos motivos ou à via processual adequada, [...].

De seu ângulo os "atos políticos são os que, praticados por agentes do Governo, no uso de competência constitucional, se fundam na ampla liberdade de apreciação da conveniência ou oportunidade de sua realização, sem se aterem a critérios jurídicos preestabelecidos. São atos governamentais por excelência, e não apenas de administração. São atos de condução dos negócios públicos, e não simplesmente de execução de serviços públicos. Daí seu maior discricionarismo e, conseqüentemente, as maiores restrições para o controle judicial. Mas nem por isso afastam a apreciação da Justiça quando argüidos de lesivos a direito individual ou ao patrimônio público.

A conceituação dos chamados Atos Politicos tem desafiado a argúcia dos publicistas, sem chegarem a uma definição coincidente e satisfatória. A dificuldade está em que, a nosso ver, não há uma categoria de atos políticos, como entidade ontológica autônoma na escala dos atos estatais, nem há um órgão ou Poder que os pratique com privatividade. Todos os Poderes de Estado são autorizados constitucionalmente a praticar determinados atos, em determinadas circunstâncias, com fundamento político. Nesse sentido, pratica Ato Político o Executivo quando veta projeto de lei, quando nomeia Ministro de Estado, quando concede indulto; pratica-o o Legislativo quando rejeita veto, quando aprova contas, quando cassa mandato; 
pratica-o o Judiciário quando propõe a criação de tribunais inferiores, quando escolhe advogado e membro do Ministério Público para compor o quinto constitucional. Em todos esses exemplos são as conveniências do Estado que comandam o ato e infundem-lhe caráter político que o torna insuscetível de controle judicial quanto à valoração de seus motivos.

Mas, como ninguém pode contrariar a Constituição e essa mesma Constituição veda se exclua da apreciação do Poder Judiciário qualquer lesão ou ameaça a direito, individual ou coletivo (art. $5^{\circ}$, XXXV), segue-se que nenhum ato do Poder Público deixará de ser examinado pela Justiça quando argüido de inconstitucional, de lesivo de direito subjetivo de alguém. Não basta a simples alegação de que se trata de Ato Político para tolher o controle judicial, pois será sempre necessário que a própria Justiça verifique a natureza do ato e suas conseqüências perante o direito individual do postulante. $\mathrm{O}$ que se nega ao Poder Judiciário é, depois de ter verificado a natureza e os fundamentos políticos do ato, adentrar seu conteúdo e valorar seus motivos."

Afirma, em coerência com o texto deste trabalho, que o Direito brasileiro atribui ao

[...] ato político ou de governo relevância totalmente diversa da que lhe é conferida pela doutrina européia. Esta os concebe para efeitos de qualificá-los com atos insuscetíveis de controle jurisdicional, entendimento que repelimos de modo absoluto e que não se coadunaria com o Texto Constitucional brasileiro, notadamente o art. $5^{\circ}, \mathrm{XXXV} .{ }^{40}$

Perde o Ato, quando contrário à Constituição, seu matiz de exclusivamente Político ou de Governo, tornando-se, desse modo, judicializável, ou seja, sujeito à sindicabilidade judiciária.

Consubstanciando medidas de objetivos estritamente políticos finalidade - movimentando-se na área interna da ação governamental jamais lesando direitos individuais, explicitados em texto claro de lei, mas podendo ferir tão-só interesses - conteúdo -, desponta o Ato Político ou de Governo em toda sua pureza, incontrastável, nessas condições, pelo Poder Judiciário, que não o examina, em si, de imediato, podendo, porém, chegar até ele se, dele, resultarem outros atos, que de modo indireto afetem direitos subjetivos. 


\section{CONCLUSÃO}

Só é possível uma compreensão razoável da judiciabilidade dos Atos Políticos ou de Governo no Brasil a partir de uma tomada historicista dos diversos períodos que determinaram o evolver do pensamento constitucional pátrio.

A Teoria dos Atos Políticos ou de Governo e sua judiciabilidade está assentada no Direito brasileiro, na praxis, a partir 1892.

Atos Políticos ou de Governo são aqueles que, praticados discricionariamente em nome de um dos poderes constituídos da Nação - por isso a matéria é política, porque respeitante à Nação, e não aos direitos individuais - não lesam direitos constitucionais dos cidadãos e não afetam prejudicialmente interesses de ordem pública.

As Constituições, exclusive a de 1934, são omissas quanto a regulação da judiciabilidade dos Atos Políticos ou de Governo mas, a par de ser tal judiciabilidade da essência do Regime Jurídico Constitucional, daí ser prescindível mesmo sua previsão expressa, tem-se que o art. $5^{\circ}$, XXXV, da Constituição de 05 de outubro de 1988, sob a epígrafe "Dos Direitos e Garantias Fundamentais", supre tal omissão na medida em que textualmente estabelece: "A lei não excluirá da apreciação do Poder Judiciário lesão ou ameaça a direito".

Desde 1892 até a hodiernidade a doutrina jurídica brasileira tem se conduzido no sentido de afirmar a judiciabilidade dos Atos Políticos ou de Governo quando praticados além dos termos constitucionalmente previstos.

\section{REFERÊNCIAS}

ALESSI, Renato. Instituciones de derecho administrativo. 3. ed. Barcelona: BOSCH. 1970. t. I.

BARBOSA, Ruy. Os actos inconstitucionaes: do Congresso e do Executivo ante a Justiça Federal. Rio de Janeiro: Companhia Impressora, 1903.

O estado de sítio: sua natureza, seus effeitos, seus limites. Rio de Janeiro: Companhia Impressora, 1892. 
BIELSA, Rafael. Derecho administrativo. 3. ed. Buenos Aires: J. Lajouane y Cia, 1937. v. I.

. Compendio de derecho publico. Buenos Aires: Llordén, 1952.

BRASIL. Constituição (1988). Constituição da República Federativa do Brasil: quadro comparativo. Brasília:Senado Federal,Subsecretaria de Edições Técnicas, 1991.

CAETANO, Marcello. Manual de direito administrativo. 10. ed. Coimbra: Almedina, 1997. v. 1.

CHINCHILLA MARIN, C; LOZANO, B.; DEL SAZ, S. "Reflexiones en torno a la polémica sobre el origen del Derecho Administrativo". In: . "Nuevas perspectivas del derecho administrativo. Tres estudios". Madrid: Civitas, 1992.

CRETELLA JÚNIOR, José. Curso de direito administrativo. Rio de Janeiro: Forense. 1989.

. Tratado de direito administrativo. São Paulo: Forense. 1966. V. I.

CUENCA, Núria Garrido. El acto de gobierno. Barcelona: Cedecs Editorial. 1998.

CUNHA, Alexandre Sanches. Todas as constituições brasileiras de 1824 a 1988. Campinas: Bookseller, 2001.

DEL SAZ, S.; CHINCHILLA MARIN, C.; LOZANO, B. "Reflexiones en torno a la polémica sobre el origen del Derecho Administrativo". In: Nuevas perspectivas del derecho administrativo: Tres estudios. Madrid: Civitas.

DI PIETRO, Maria Sylvia Zanella. Direito administrativo. 16. ed. São Paulo: Atlas, 2003.

DUEZ, P. Les actes de gouvernement. Paris: Sirey, 1935.

ENTERRÍA, Eduardo García; FERNÁNDEZ, Tomás-Ramón. Curso de derecho administrativo I. Madri: Civitas, 1977.

FERNÁNDEZ, Tomás-Ramón; ENTERRÍA, Eduardo García. Curso de derecho administrativo I. Madri: Civitas, 1977. 
FUNDAÇÃO Casa de Rui Barbosa. Rui Barbosa e a Constituição de 1891. Rio de Janeiro: Fundação Casa de Rui Barbosa, 1985. 1v.

LACOMBE, Américo Jacobina. In apresentação à obra Rui Barbosa e a constituição de 1891. 1985.

LOZANO, B.; DEL SAZ, S.; CHINCHILLA MARIN, C. Reflexiones en torno a la polémica sobre el origen del Derecho Administrativo. In: Nuevas perspectivas del derecho administrativo. Tres estudios. Madrid: Civitas. 1992.

MALBERG, Carré R. Teoría general del estado. Tradução José Lion Depetre. México: Fondo de Cultura Econômica, 2001.

MEIRELLES, Hely Lopes. Direito administrativo brasileiro. 28. ed. São Paulo: Malheiros Editores, 2003.

MELLO, Celso Bandeira de. Curso de direito administrativo. 16. ed. São Paulo: Malheiros Editores, 2003.

MELLO, Oswaldo Aranha Bandeira de. Princípios gerais de direito administrativo. 2. ed. Rio de Janeiro: Forense. 1979. v. 1.

MIRANDA, Jorge. Manual de direito constitucional. t. IV. $2^{\mathrm{a}}$ ed. Coimbra: Coimbra Editora. 1998.

Funções, órgãos e actos do Estado. Lisboa: FDUL, 1990.

MIRKINE-GUETZÉVITCH, B. As novas tendencias do direito constitucional. Tradução: Candido Motta Filho. São Paulo: Nacional, 1933.

REIS, Aarão. Direito administrativo. Rio de Janeiro: Livraria Francisco Alves, 1923.

SANCHES MORON. El control de las administraciones públicas y sus problemas. Madrid: Instituto de España.

SCHWARTZ, Bernard. Direito constitucional americano. Tradução: Carlos Mayfeld. Rio de Janeiro: Forense, 1966.

TRÍPOLI, César. História do direito brasileiro. São Paulo: Revista dos Tribunais, 1936. v. I.

URUGUAI, Visconde de. Ensaio sôbre o direito administrativo. Rio de Janeiro: Departamento de Imprensa Nacional, 1960. 


\section{VARNHAGEN, Francisco Adolfo de. História geral do Brasil: antes de sua separação e independência de Portugal. 4. ed. São Paulo: Melhoramentos. 1948. Tomos I, II, III, IV e V.

\author{
VIEIRA, Oscar Vilhena. Supremo Tribunal Federal: jurisprudência \\ política. São Paulo: Revista dos Tribunais. 1994..
}

\section{NOTAS}

1 BARBOSA, Ruy. Os actos inconstitucionaes: do Congresso e do Executivo ante a Justiça Federal. Rio de Janeiro: Companhia Impressora, 1903. p. 101.

2 DUEZ, P. Les actes de gouvernement. Paris: Sirey. 1935. p. 23-79 e segs.

3 CHINCHILLA MARIN, C. "Reflexiones en torno a la polémica sobre el origen del Derecho Administrativo". In "Nuevas perspectivas del Derecho Administrativo. Tres estudios". Madrid: Civitas. . p. 30. Obra em co-autoria com LOZANO, B. e DEL SAZ, S.

4 SANCHES MORON, Miguel. El control de las administraciones públicas y sus problemas. Madrid: Instituto de España. 1991. p. 26.

5 CUENCA, Núria Garrido. El acto de gobierno. Barcelona: Cedecs Editorial. 1998. p. 52.

6 Conseil d'Etat (en adelant CE, 1 de mayo de 1822, Lafitte, Recueil Lebon (en adelante R. Lebon), 1822, p. 571.

7 CE, 9 de mayo de 1867, Duc d'Aumale et Michel Lévy, R. Lebon, 1867, p. 472, y Dalloz 18673-49, Conclusiones Aucoc.

8 CUENCA, Núria Garrido. El acto de gobierno. Barcelona: Cedecs Editorial. 1998. ps. 51-76.

9 CUENCA, Núria Garrido. El acto de gobierno. Barcelona: Cedecs Editorial. 1998. p. 73.

10 Ibid., p. 58.

11 CUENCA, Núria Garrido. El acto de gobierno. Barcelona: Cedecs Editorial. 1998. p. 58.

12 Ibid., p. 58.

13 MALBERG, Carré R. Teoría general del estado. Tradução José Lión Depetre. México: Fondo de Cultura Económica. 2001. ps. 482-485.

14 BIELSA, Rafael. Derecho administrativo. 3. ed. Buenos Aires: J. Lajouane y Cia. 1937. p.146. v. I.

15 Apud MALBERG, Carré R. Teoría general del estado. Tradução José Lión Depetre. México: Fondo de Cultura Económica. 2001. p. 483.

16 CUENCA, Núria Garrido. El acto de gobierno. Barcelona: Cedecs Editorial. 1998. p. 77-133.

17 MIRANDA, Jorge. Funções, órgãos e actos do Estado. Lisboa: FDUL. 1990. p. 28-37.

18 TRÍPOLI, César. A história do direito brasileiro. São Paulo: Revista dos Tribunais. 1936. ps. 28 e segs. v. I.

19 "Parece que os concílios da monarquia vizigoda - em que era elemento preponderante o clero - são a origem remota das assembléias que, na História da Península Ibérica, ficaram qualificadas, afinal, como Côrtes. (Conf. REIS, Aarão. Direito administrativo. Rio de Janeiro: Livraria Francisco Alves. 1923. p. 88).

20 REIS, Aarão. Direito administrativo. Rio de Janeiro: Livraria Francisco Alves, 1936. p. 99.

21 Ibid., p. 99.

22 REIS, Aarão. Direito administrativo. Rio de Janeiro: Livraria Francisco Alves, 1936. p. 99.

23 REIS, Aarão. Direito administrativo. Rio de Janeiro: Livraria Francisco Alves, 1936. p. 84102.

24 CONSTANT, Benjamim. Apud URUGUAI, Visconde de. Ensaio sôbre o direito administrativo. Rio de Janeiro: Departamento de Imprensa Nacional, 1960, p. 254: “Les trois pouvoirs politiques, tels qu'on les a connu justiqu'ici, le pouvoir legislatif, exécutif et judiciaire, sont trois ressorts qui doivent coopérer, chacun dans sa partie, au mouvement, general; mais quand ces ressorts détrangés se croisent, s'entrechoquent, et s'entravent, il faut une force qui les remette à leur place. Cette force ne peut pas être dans l'un de ces ressorts, car 
elle lui servirait à détruire les autres; il faut qu'elle soit en dehors, qu'elle soit neutre en quelque sorte, pour que son action s'applique partout ou il est nécessaire qu'elle soit appliquée, et pour qu'elle soit préservatrice, et réparatrice sans être hostile.

"La Monarchie Constitutionnelle a ce grand avantage, qu'elle crée ce pouvoir neutre dans la personne d'un Roi, déjà entouré de traditions et de souvenirs, et, revêtú d'une puissance d'opinion qui sert de base à sa puissance politique. L'intérêt véritable de ce Roi n'est aucunement que l'un de ces pouvoirs renverse l'autre, mais que tous s'appuient, s'entendent, et, agissent de concert."

25 URUGUAI, Visconde de. Ensaio sobre o direito administrativo. Rio de Janeiro: Departamento de Imprensa Nacional. 1960. p. 134 et seq.

26 CUENCA, Núria Garrido. El acto de gobierno. Barcelona: Cedecs Editorial. 1998. p. 93-95.

27 VIEIRA, Oscar Vilhena. Supremo Tribunal Federal: jurisprudência política. São Paulo: Revista dos Tribunais. 1994. p. 23-38.

28 LACOMBE, Américo Jacobina. In: APRESENTAÇÃO à obra Rui Barbosa e a constituição de 1891. Rio de Janeiro: Fundação Casa de Rui Barbosa. 1985.

29 BARBOSA, Ruy. O estado de sítio: sua natureza, seus efeitos, seus limites. Rio de Janeiro: Companhia Impressora, 1892. 278 p.

30 BARBOSA, Ruy. Os actos inconstitucionaes: do Congresso e do Executivo ante a Justiça Federal. Rio de Janeiro: Companhia Impressora, 1903. p. 145-161.

31 BARBOSA, Ruy. Os actos inconstitucionaes: do Congresso e do Executivo ante a Justiça Federal. Rio de Janeiro: Companhia Impressora, 1903. p. 26-27.

32 BARBOSA, Ruy. Os actos inconstitucionaes: do Congresso e do Executivo ante a Justiça Federal. Rio de Janeiro: Companhia Impressora. 1903. p. 43-44.

33 BARBOSA, Ruy. Os actos inconstitucionaes: do Congresso e do Executivo ante a Justiça Federal. Rio de Janeiro: Companhia Impressora. 1903. p. 50.

34 BARBOSA, Ruy. Os actos inconstitucionaes: do Congresso e do Executivo ante a Justiça Federal. Rio de Janeiro: Companhia Impressora. 1903. p. 182-183.

35 CRETELLA JÚNIOR, José. Curso de direito administrativo. Rio de Janeiro: Forense. 1989. p. 230-236.

36 BARBOSA, Ruy. Os actos inconstitucionaes: do Congresso e do Executivo ante a Justiça Federal. Rio de Janeiro: Companhia Impressora. 1903. p. 60.

37 DI PIETRO, Maria Sylvia Zanella. Direito administrativo. 16. ed. São Paulo: Atlas, 2003. p. 617.

38 MELLO, Celso Bandeira de. Curso de direito administrativo. 16. ed. rev. atual. São Paulo: Malheiros Editores, 2003. p. 351-352.

39 MEIRELLES, Hely Lopes. Direito administrativo brasileiro. 28. ed. atual. São Paulo: Malheiros Editores, 2003. p. 679-680.

40 MELLO, Celso Antônio Bandeira de. Curso de direito administrativo. 16. Ed. São Paulo: Malheiros, 2003. p. 352.

Artigo recebido em: 18/09/2008

Aprovado para publicação em: 10/12/2008 